\title{
Formulation of functional beverages from the combination of lime, tomato, and carrot using foam-mat drying method
}

\author{
Kartini Kartini*, Alfian Hendra Krisnawan, Lisa Calista Silvanus, \\ Tiffanny Putri Wijaya \\ Department of Pharmaceutical Biology, Faculty of Pharmacy University of Surabaya
}

Submitted: 17-09-2019

Reviewed: 05-11-2019

Accepted: 29-11-2019

\begin{abstract}
Lime, tomato, and carrot are natural ingredients widely used both as food and herbal medicines particularly because these plants contain various antioxidant compounds such as vitamin $\mathrm{C}$, phenolics, flavonoids, and carotenoids. Since these materials are easily damaged when exposed to high temperatures, any processing methods that involve slight quality changes in the final product are favorable. This study aimed to formulate lime, tomato, and carrot into functional beverages using foam-mat drying method. Lime juice combined with either tomato paste or carrot juice was mixed with egg white and methylcellulose as foaming agents, then whipped using a mixer for 10 minutes to form a stable foam. The foam was placed in a stainless tray, flattened, and dried in an oven at $60^{\circ} \mathrm{C}$ for 5 hours. Once dried, the mass was scraped using a spatula, and the resultant dry powder was then evaluated for its physical characteristics and antioxidant activities using nitrite oxide (NO) method. The produced dry mass of lime, lime-tomato (1:1), and lime-carrot (1:1) had organoleptic characteristics, water content, sugar content, and food additives content in accordance with the Indonesian National Standard (SNI). Also, with the $\mathrm{IC}_{50}$ values of 4248,4931 , and $4218 \mu \mathrm{g} / \mathrm{ml}$, the lime juice and its combination with tomatoes (1:1) and carrots $(1: 1)$ can be formulated into functional powder drinks that comply with the SNI quality requirements. Lime-carrot is a better combination than lime-tomato.
\end{abstract}

Keywords: formulation, functional beverages, lime, foam-mat drying

*Corresponding author:

Kartini

Department of Pharmaceutical Biology, Faculty of Pharmacy, University of Surabaya

Email: kartini@staff.ubaya.ac.id 


\section{INTRODUCTION}

When released into the air, most chemicals, heavy metals, and smoke trigger the reaction of oxidation that forms free radicals and causes air pollution. This reaction is continuous and multiplied, resulting in various pathological conditions, such as cardiovascular diseases and cancer (Shebis et al., 2013). Oxidation can be prevented, delayed, or eliminated with antioxidants, one of which can be obtained from natural ingredients (Pyrzynska and Pękal, 2013).

Lime (Citrus aurantifolia) contains many active compounds, including flavonoids - such as apigenin, hesperetin, kaempferol, nobiletin, quercetin, rutin, flavones, flavanones, naringenin, triterpenoid, and limonoids (Narang and Jiraungkoorskul, 2016). Lime is a citrus fruit that is available throughout the year. Unfortunately, its abundance at a certain time causes lime to be underutilized. During large harvests, its selling price even drops significantly (Kartini et al., 2018; Oikeh et al., 2016). Other fruits and vegetables found in plentiful numbers that also contain antioxidant constituents are tomatoes (Solanum lycopersicum) and carrots (Daucus carota). In addition to vitamin C, natural antioxidant compounds contained in tomato and carrot are lycopene and $\beta$-carotene (carotenoids), flavonoids, and phenolic acids (Frusciante et al., 2007; Sahlin et al., 2004). One way to increase the added value and utilization of these natural ingredients is by processing them into functional food/beverage products. Functional food is food that not only is necessary for sustaining lives but also functions as a source of mental and physical well-being enhancer. Furthermore, it contributes to the prevention and reduction of risk factors of several diseases and enhances certain physiological functions. A food can be regarded as functional if it satisfactorily demonstrates its positive effects on one or more target functions in the body beyond the adequate nutritional effects and in a way that is relevant to maintaining or promoting either the state of well-being and health or the reduction of risk of a disease or other pathologic processes (Lobo et al., 2010). The Indonesian Food and Drug Agency defines functional food as processed food containing one or more functional components, which according to scientific studies have specific physiological functions and are proven to be harmless but beneficial to health (BPOM, 2005).

There is a wide variety of functional foods, from the simplest form like whole foods to the one processed with certain technologies. Foam-mat drying is a method of processing ingredients into functional foods using a relatively low temperature. This technique is therefore suitable for processing lime, tomatoes, and carrots into powder drink while maintaining the stability of their chemical compounds. Foam-mat drying is a process by which a liquid or semi-liquid is whipped to form a stable foam and, subsequently, dehydrated by thermal means (Karim and Wai, 1999). The combination of lime with tomatoes or carrots is considered appropriate to increase consumer acceptance pertaining to taste while maintaining their antioxidant activity. This study was designed to formulate the functional powder beverage from lime-tomato and lime-carrot combination by foam-mat drying method. The characteristics of the final products were evaluated to assess their compliance with the criteria issued in the Indonesian National Standard (SNI). Also, the antioxidant activities of a single lime product, its combination with tomato, and its combination with carrot were also evaluated.

\section{MATERIALS AND METHODS \\ Materials}

The plant materials used were limes (Citrus aurantifolia) harvested in September-October 2017, from lime plantations in Tinggar Village, Bandarkedungmulyo District, Jombang Regency, East Java. Meanwhile, the tomatoes (Solanum lycopersicum) and carrots (Daucus carota) were purchased from the Traditional Market Soponyono in Surabaya. Each of these plant materials were determined by the Center for Information and Development of Traditional Medicine (PIPOT), University of Surabaya (certificates number: 1255/D.T/IX/2017; 1259/D.T/X/2017; 1260/D.T/X/2017). The chemicals included sodium nitroprusside (Sigma), Griess reagent kit (Promega), phosphate-buffered saline 
(PBS), vitamin C (pharmaceutical grade), methylcellulose (food grade), sucrose (food grade), and egg white.

\section{Methods \\ Formulation of functional powder drinks}

The functional beverage made of lime and its combination with either tomato or carrot was prepared according to the formula described in Table I.

Table I. The formula of functional lime beverages

\begin{tabular}{llll}
\hline Ingredients & \multicolumn{3}{c}{ Compositions (g) } \\
& F1 & F2 & F3 \\
\hline Lime paste & 100 & 50 & 50 \\
Tomato paste & 0 & 50 & 0 \\
Carrot juice & 0 & 0 & 50 \\
Methylcellulose & 15 & 15 & 15 \\
Egg white & 1.5 & 1.5 & 1.5 \\
Sucrose & $q s$ & $q s$ & $q s$ \\
& & & \\
\hline
\end{tabular}

First, the collected limes and tomatoes were washed and peeled. After removing the seeds, the flesh of these fruits was crushed with a blender for 1 minute until a smooth paste was formed. Also, the carrots were peeled, thinly sliced $( \pm 5 \mathrm{~mm})$, and crushed in a blender for 2 minutes, then the juice was collected. Second, lime paste, tomato paste, and carrot juice were weighed according to the formula presented in Table 1, added with the appropriate amount of methylcellulose and egg white, and stirred using a mixer for 10 minutes until a stable foam mass was formed. Then, the resultant foam was weighed, flattened on a baking sheet, and dried in an oven at $60^{\circ} \mathrm{C}$ for 5 hours. Finally, the dried products were scraped using a spatula. The mass of the dry powder was weighed, and the recovery was determined with the following equation:

$$
\text { Yield }(\%)=\frac{\text { dry powder obtained }(\text { gram })}{\text { mass of foam used }(\text { gram })} \times 100 \%
$$

After the dry powder was formed, sucrose was added with a ratio of 1:5, mixed with a blender, then stored in airtight containers.

\section{Organoleptic observation and moisture content analysis}

The form, odor, taste, and color of the functional powder drinks were observed, both before and after the addition of sucrose. Also, the moisture content of the product before and after the addition of sugar was measured using a Moisture Content Balance.

\section{Determination of antioxidant activity}

In this step, the functional drinks were analyzed for their antioxidant activity by the NO radical scavenging method (Harput et al., 2012). This analysis used Griess reagent (1\% sulfanilamide, $0.1 \%$ naphthyl ethylenediamine dihydrochloride, $2.5 \% \mathrm{H}_{3} \mathrm{PO}_{4}$ ) that was first calibrated using a standard solution of nitrite. After serial dilution, fifty $\mu \mathrm{l}$ of the diluted samples were added into a 96-well microplate. Subsequently, $50 \mu 1$ of $11.7 \mathrm{mM}$ sodium nitroprusside (SNP), dissolved in phosphatebuffered saline (PBS), were added to each well, and the plate was incubated in the dark at room temperature for 150 minutes. Then, $50 \mu \mathrm{l}$ of sulfanilamide (SA) was added into each well, and the plate was incubated for 10 minutes. Finally, $50 \mu \mathrm{l}$ of naphthyl ethylenediamine dihydrochloride (NED) 
was added into each well, and the plate was incubated again for another 10 minutes. After the chromophore was formed, its absorbance was measured at $546 \mathrm{~nm}$ in a microplate reader. The capacity of $\mathrm{NO}$ radical scavenging was calculated using the equation below:

$$
\text { Scavenging }(\%)=\frac{\text { absorbance of blank }- \text { absorbance of sample }}{\text { absorbance of blank }} \times 100 \%
$$

The concentration that produced $50 \%$ radical scavenging $\left(\mathrm{IC}_{50}\right.$ value) was extrapolated using the linear regression equation of concentration versus \%inhibition.

\section{RESULTS AND DISCUSSION}

\section{Formulation and characteristics of the functional powder beverages}

Foam-mat drying is a simple and cost-efficient drying method for the production of food powders. It can be applied as an alternative to drum, spray, and freeze-drying. The raw liquid material is converted into a stable foam by adding foaming agents, either in the presence or absence of foam stabilizers, through the process of beating or whipping and dried by a continuous flow of hot air and different temperatures. There have been recent applications of this technique to process various fruit commodities, such as apple, starfruit, lime, mango, banana, and tomato (Dehghannya et al., 2018; Iswari, 2016; Kadam and Balasubramanian, 2011; Karim and Wai, 1999; Raharitsifa et al., 2006; Wilson et al., 2012). In this work, the foam-mat drying method was applied on lime and its combination with either tomato or carrot.

The final products of the foam-mat drying, which are functional beverages formulated from lime, tomato, and carrot can be seen in Figures 1 and 2. The dry yields of lime, lime-tomato, and limecarrot processing were $11.31 \pm 2.72 \%, 7.76 \pm 1.33 \%$, and $11.34 \pm 2.83 \%$, respectively. In this study, the addition of carrot did not change the yield, but when added with tomato, the yield of lime functional powder drinks was actually reduced.

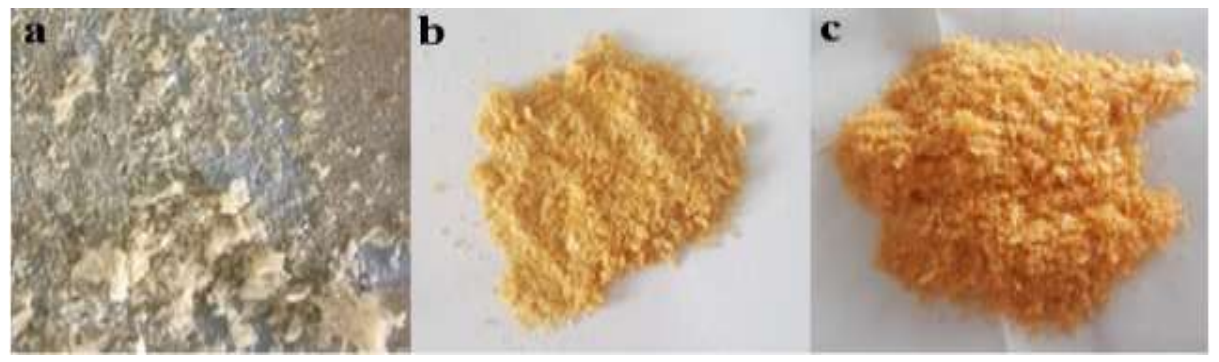

Figure 1. Foam-mat drying products before sucrose addition: lime (a), lime-tomato (b), limecarrot (c)

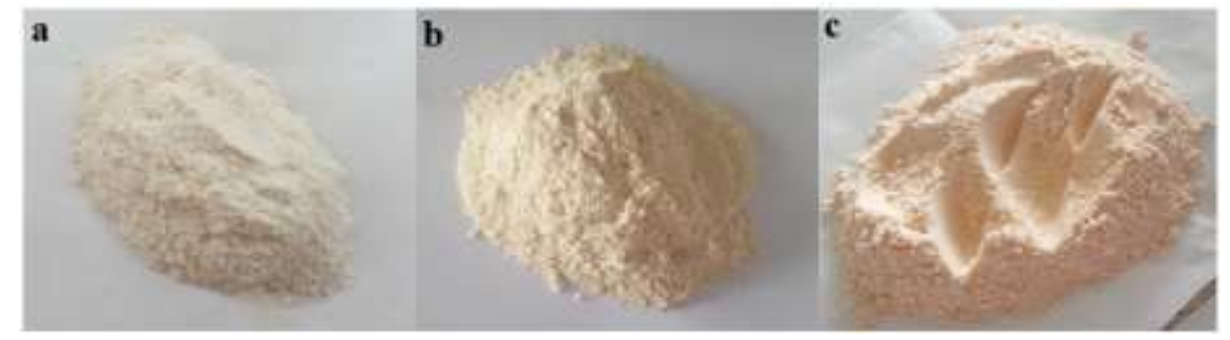

Figure 2. Foam-mat drying products after sucrose addition: lime (a), lime-tomato (b), lime-carrot 
The characteristics of the products were then evaluated and compared to the criteria set in the Indonesian National Standard (SNI 01-4320-1996) for powder of traditional drink (Nasional, 1996). This comparison is presented in Table II.

Table II. The characteristics of the lime-based functional foods in comparison with SNI criteria

\begin{tabular}{|c|c|c|c|c|c|}
\hline Criteria & SNI & $\begin{array}{c}\text { Powder of } \\
\text { lime }\end{array}$ & $\begin{array}{c}\text { Powder of } \\
\text { lime-tomato }\end{array}$ & $\begin{array}{c}\text { Powder of } \\
\text { lime-carrot }\end{array}$ & Suitability \\
\hline Form & Normal & Fine powder & Fine powder & Fine powder & Yes \\
\hline Odor & $\begin{array}{l}\text { Typical } \\
\text { spice }\end{array}$ & Typical lime & $\begin{array}{l}\text { Typical lime- } \\
\text { tomato }\end{array}$ & $\begin{array}{l}\text { Typical lime- } \\
\text { carrot }\end{array}$ & Yes \\
\hline Color & Normal & Light yellow & Reddish yellow & Light orange & Yes \\
\hline Taste & Normal & Sour-bitter & Rather sour & Rather sour & Yes \\
\hline $\begin{array}{c}\text { Water content } \\
(\%)\end{array}$ & $\underset{5}{\text { Maximum }}$ & 1.25 & 1.60 & 1.57 & Yes \\
\hline $\begin{array}{c}\text { Sucrose content } \\
(\%)\end{array}$ & $\begin{array}{l}\text { Maximum } \\
85\end{array}$ & 83.33 & 83.33 & 83.33 & Yes \\
\hline Saccharin $(\%)$ & 0 & 0 & 0 & 0 & Yes \\
\hline Cyclamate $(\%)$ & 0 & 0 & 0 & 0 & Yes \\
\hline $\begin{array}{l}\text { Food coloring } \\
(\%)\end{array}$ & 0 & 0 & 0 & 0 & Yes \\
\hline
\end{tabular}

When compared with the quality requirements issued in SNI 01-4320-1996, the functional powder drinks of lime, lime-tomato, and lime-carrot produced in this study meet the SNI criteria in terms of form, color, odor, taste, water content, sugar content, and food additives (sweeteners and dyes) content. Before the addition of sucrose, all products showed crumb texture, making them easily reduced into fine powder. The addition of sucrose followed by grinding resulted in fine powder, and this form is easily reconstituted. Lime powder had a light yellow color, whereas lime-tomato and limecarrot produced reddish yellow and light orange powder, respectively. These colors resemble the original color of each paste and juice, indicating that the chemical compounds have remained stable throughout the drying process. Although the combination of lime with tomato or carrot produced lower or equal yield, this combination formula yielded a finer product and a less bitter-sour taste compared to a single lime formula. Table II also shows that the water content of all products is below the maximum limit. For this reason, the products can be stored for a certain period of time without allowing microorganisms to overgrow. The water content in this products, especially lime-carrot $(1.57 \%)$ is better than a previous similar study in which the water content of carrot powder prepared using foam-mat drying is $2.1 \%$ (Iswari, 2016).

Various factors determine the characteristics of the foam-mat drying product, including the type and concentration of the foaming agents, foam stabilizers, foaming methods, temperature, and the duration of the drying. A foaming agent is a surfactant material that reduces the surface tension between two liquids or between a liquid and a solid and facilitates the foam formation. Not only do proteins promote a good foaming ability, but they also create high foam stability. Among the most widely used proteins as foaming agents are egg white, gelatin, milk proteins like whey protein, casein, and soy protein. During the whipping process, proteins denature at the gas-liquid interface and interact with one another, forming stable, visco-elastic interfacial films and, finally, foam. Foams stabilized with egg white usually collapse after $20 \mathrm{~min}$ of whipping. Due to this instability, ingredients functioning as foam stabilizers need to be added to enhance the stability of foam over time. Generally, polysaccharides are used as stabilizers, which improve the stability of foam proteins through the thickening or gelling effects of the aqueous solution. Carboxymethylcellulose (CMC) is the most 
common foam stabilizer used in many studies. It is often added to food in its sodium salt form (Mounir, 2017).

This current study used around $1.3 \%$ egg white as the foaming agent. This application is in accordance with previous research that has found that $3 \%$ of egg white is better than 5 and $7 \%$ in the foam-mat drying of mango pulp. Three percent of egg white is considered excellent due to its effective drying rate. Although 5 and 7\% egg white induced similar drying rates of the mango pulp, their higher concentrations are necessarily avoided to prevent excessive use of foaming agents (Mounir, 2017; Wilson et al., 2012). Moreover, in the case of foam-mat drying of apple juice, the optimal concentrations of methylcellulose and egg white to obtain the most solid foams are $0.2 \%$ and 2-3\%, respectively (Raharitsifa et al., 2006). Methylcellulose was used as foam stabilizer in this study because methylcellulose-foams usually are mechanically and thermodynamically stable.

While an increase in drying temperature reduces drying time, the stability of the active compounds needs to be taken into consideration. The drying temperature of $60^{\circ} \mathrm{C}$ was selected considering that antioxidant compounds of lime, tomato, and carrot, namely flavonoids, carotenoids, and vitamin $\mathrm{C}$, are stable at this temperature. Wilson et al., 2012 confirm that at $65^{\circ} \mathrm{C}$, the drying process produces the highest total carotene content in the mango pulp compared to 75 and $85^{\circ} \mathrm{C}$ (Wilson et al., 2012).

Foam-mat drying can be considered as a method of producing functional food. When compared with other drying methods such as spray-drying or drum-drying, this technique offers several advantages, including lower drying temperature and shorter drying time. These advantages are attributable to the larger surface area exposed to the stream of hot airflow, which accelerates the moisture removal process. The foam-mat drying process is relatively inexpensive and straightforward that it can be applied to industries at household scale. Iswari suggests that foam-mat drying takes only six hours to dry carrot juice, whereas drying without foam formation completes in 96 hours (Iswari, 2016). The application of foam-mat drying technique for lime is expected to increase the added value and stability of the product in the storage for a more extensive marketing.

There has been, however, one difficulty with this process, which is the lack of stability of the foam during the heating cycle. If the foam does not remain stable, cellular breakdown occurs and causes serious impairment to the drying operation. Many variables affecting foam formation, density, and stability have been reported, and these include the chemical nature of the fruit, soluble solids, pulp fraction, and the type and concentration of the foaming agent and foam stabilizer (Karim and Wai, 1999). Therefore, all these parameters need to be optimized before applying foam-mat drying to certain commodities.

\section{The antioxidant activity of lime functional beverages}

This study employed the reduction of nitrite oxide (NO), a free radical, using Griess reagent for antioxidant activity testing. Griess reagent consists of $1 \%$ sulfanilamide, $0.1 \%$ naphthyl ethylenediamine dihydrochloride, and $2.5 \% \mathrm{H}_{3} \mathrm{PO}_{4}$, and for this analysis, it requires calibration before use. The result of the calibration on Griess reagent used in this study can be seen in Figure 3. This graph shows $\mathrm{R}^{2}=0.9962$, indicating that there is a linear correlation between the concentration of nitric oxide solution and absorbance. In other terms, Griess reagent is appropriate to be used in determining NO inhibition activity. 


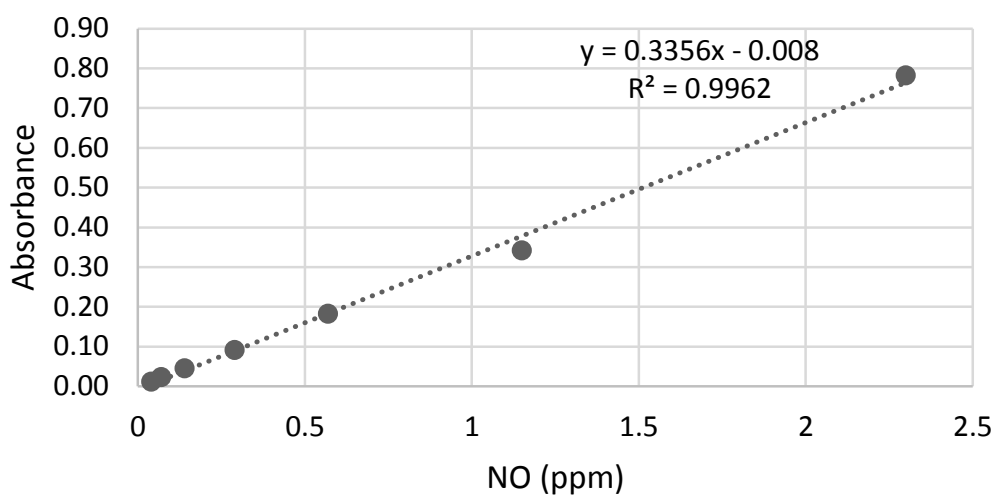

Figure 3. The calibration curve of the NO standard

The percentage of NO reduction by lime, lime-tomato, and limes-carrot powder drinks are presented in Figure 4, while the $\mathrm{IC}_{50}$ values of each sample and vitamin $\mathrm{C}$ are shown in Table III.

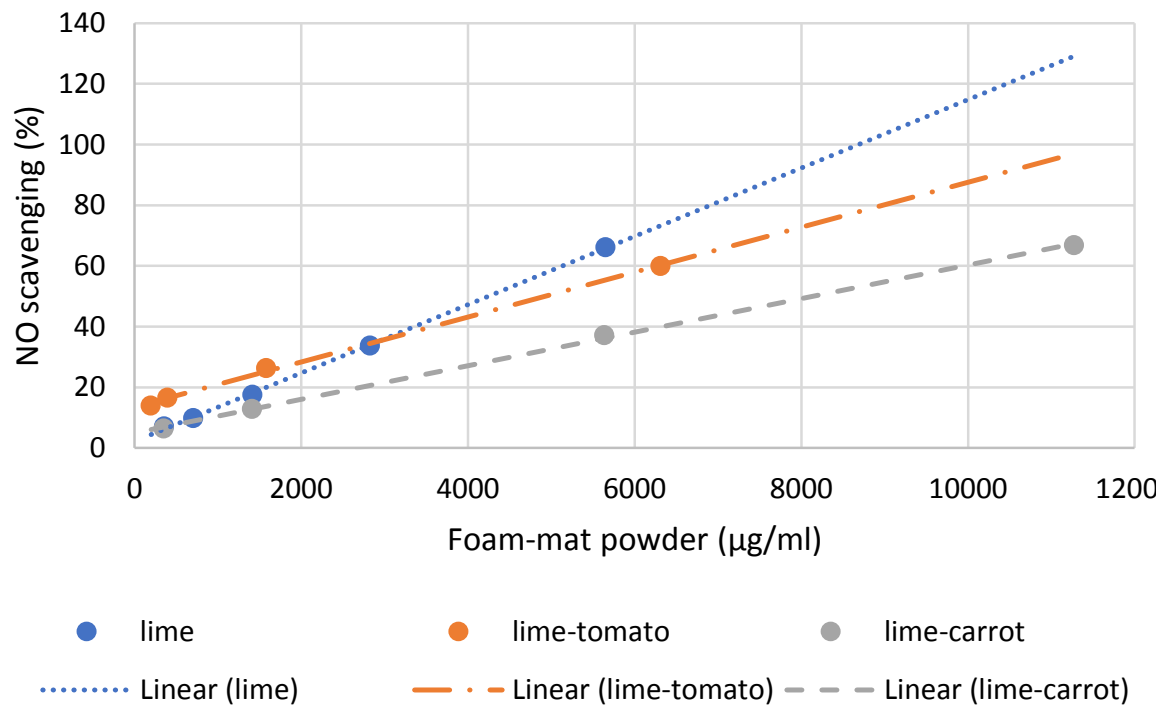

Figure 4. The nitrite oxide scavenging activities of the produced lime, lime-tomato, and limecarrot powder drinks

Table III. The $\mathrm{IC}_{50}$ values of lime powder and its combination

\begin{tabular}{cc}
\hline Samples & IC $_{\mathbf{5 0}}(\boldsymbol{\mu g} / \mathbf{m l})$ \\
\hline Lime powder & $4248 \pm 120^{\mathrm{a}}$ \\
Lime-tomato powder & $4931 \pm 108^{\mathrm{b}}$ \\
Lime-carrot powder & $4218 \pm 156^{\mathrm{a}}$ \\
Vitamin C* $^{*}$ & $4.99 \pm 0.22$ \\
\hline
\end{tabular}

*Standard compound; Values are means \pm SD of four determinations, and the mean values with different letters indicate a statistically significantly difference $(\mathrm{P}<0.05)$.

The use of tomato and carrot each as a substitute for $50 \%$ of lime in the combination formula is expected to improve the physical characteristics of the product, especially in the aspect of taste, while 
maintaining its antioxidant activity. Table III shows that the $\mathrm{IC}_{50}$ values of lime powder and limecarrot powder were not significantly different, but the $\mathrm{IC}_{50}$ value of lime-tomato was significantly higher than that of single lime. These results indicate that carrot can be suitably combined or mixed with lime to improve the flavor character of the produced functional beverages. The main antioxidative compound of tomato is lycopene, which is not easily dissolved in water. Therefore, when it is added to lime, the product of this combination has a lower activity.

\section{CONCLUSION}

The lime juice and its combination with tomato (1:1) and carrot $(1: 1)$ can be formulated into functional powder drinks that meet the SNI quality requirements. When added with carrots, the resultant functional lime drink has better antioxidant activity than the one mixed with tomatoes.

\section{ACKNOWLEDGMENT}

This research was supported by the Indonesian Ministry of Research, Technology, and Higher Education with the contract research number 101/SP2H/PPM/DRPM/IV/2017.

\section{REFERENCES}

BPOM, R., 2005, Ketentuan Pokok Pengawasan Pangan Fungsional. Jakarta: Badan Pengawasan Obat dan Makanan Republik Indonesia.

Dehghannya, J., Pourahmad, M., Ghanbarzadeh, B. and Ghaffari, H., 2018, Influence of Foam Thickness on Production of Lime Juice Powder During Foam-Mat Drying: Experimental and Numerical Investigation, Powder technology, 328: 470-484.

Frusciante, L., Carli, P., Ercolano, M. R., Pernice, R., Di Matteo, A., Fogliano, V. and Pellegrini, N., 2007, Antioxidant Nutritional Quality of Tomato, Molecular nutrition \& food research, 51(5): 609-617.

Harput, U. S., Genc, Y. and Saracoglu, I., 2012, Cytotoxic and Antioxidative Activities of Plantago Lagopus L. And Characterization of Its Bioactive Compounds, Food and Chemical Toxicology, 50(5): 1554-1559.

Iswari, K., 2016, Kajian Pengolahan Bubuk Instant Wortel Dengan Metode Foam Mat Drying, Buletin Teknologi Pasca Panen, 3(1): 37-41.

Kadam, D. M. and Balasubramanian, S., 2011, Foam Mat Drying of Tomato Juice, Journal of food processing and preservation, 35(4): 488-495.

Karim, A. A. and Wai, C. C., 1999, Foam-Mat Drying of Starfruit (Averrhoa Carambola L.) Puree. Stability and Air Drying Characteristics, Food Chemistry, 64(3): 337-343.

Kartini, K., Krisnawan, A. H. and Jayani, N. I. E., 2018, Peningkatan Produktivitas Petani Dalam Pengolahan Jeruk Nipis Menjadi Produk Minuman Kesehatan Dan Sabun, Abdimas: Jurnal Pengabdian Kepada Masyarakat, 11(1): 19-26.

Lobo, V., Patil, A., Phatak, A. and Chandra, N., 2010, Free Radicals, Antioxidants and Functional Foods: Impact on Human Health, Pharmacognosy reviews, 4(8): 118

Mounir, S., 2017, Foam Mat Drying, In P. K. Nema, B. P. Kaur \& A. S. Mujumdar (Eds.), Drying Technologies for Foods-Fundamentals and Applications, India: New India Publishing Agency.

Narang, N. and Jiraungkoorskul, W., 2016, Anticancer Activity of Key Lime (Citrus Aurantifolia), Pharmacognosy Reviews, 10(20): 118-122.

Nasional, B. S., 1996, Serbuk Minuman Tradisional (Sni 01-4320-1996). Jakarta: Badan Standarisasi Nasional.

Oikeh, E. I., Omoregie, E. S., Oviasogie, F. E. and Oriakhi, K., 2016, Phytochemical, Antimicrobial, and Antioxidant Activities of Different Citrus Juice Concentrates, Food science \& nutrition, 4(1): 103-109.

Pyrzynska, K. and Pękal, A., 2013, Application of Free Radical Diphenylpicrylhydrazyl (Dpph) to Estimate the Antioxidant Capacity of Food Samples, Analytical Methods, 5(17): 4288-4295.

Raharitsifa, N., Genovese, D. B. and Ratti, C., 2006, Characterization of Apple Juice Foams for Foam- Mat Drying Prepared with Egg White Protein and Methylcellulose, Journal of Food Science, 71(3): E142E151.

Pharmaciana Vol. 9, No. 2, Nov 2019, Page. 325-334 
Sahlin, E., Savage, G. and Lister, C., 2004, Investigation of the Antioxidant Properties of Tomatoes after Processing, Journal of Food Composition and Analysis, 17(5): 635-647.

Shebis, Y., Iluz, D., Kinel-Tahan, Y., Dubinsky, Z. and Yehoshua, Y., 2013, Natural Antioxidants: Function and Sources, Food and Nutrition Sciences, 4(06): 643.

Wilson, R. A., Kadam, D. M., Chadha, S. and Sharma, M., 2012, Foam Mat Drying Characteristics of Mango Pulp, International Journal of Food Science and Nutrition Engineering, 2(4): 63-69. 
